\title{
Pengaruh Fermentasi Bakteri Asam Laktat dan Siklus Pemanasan Bertekanan-Pendinginan Terhadap Kadar Pati Resisten Tepung Ubi Jalar Ungu (Ipomea Batatas Var Ayamurasaki) Termodifikasi

\author{
Effect of Lactic Acid Bacteria Fermentation and Autoclaving-Cooling Cycle for The \\ Level Of Resistant Starch of Modified Purple Sweet Potato Flour (Ipomea Batatas \\ Var Ayamurasaki)
}

\author{
Raden Haryo Bimo Setiarto dan Nunuk Widhyastuti
}

\author{
Laboratorium Mikrobiologi Pangan, Bidang Mikrobiologi, Pusat Penelitian Biologi LIPI \\ Jalan Raya Jakarta-Bogor Km 46, Kawasan Cibinong Science Center Cibinong Bogor 16911, Jawa Barat
}

haryobimo88@gmail.com

Riwayat Naskah:

Diterima 03,2017 Direvisi 07,2017 Disetujui 07,2017
ABSTRAK: Penelitian ini bertujuan menganalisis pengaruh fermentasi kultur campuran bakteri asam laktat dan siklus pemanasan bertekanan-pendinginan terhadap kadar pati resisten tepung ubi jalar ungu termodifikasi. Irisan ubi jalar ungu difermentasi dengan kultur campuran bakteri asam laktat (Lactobacillus plantarum B-307: Leuconostoc mesenteroides SU-LS 67) (1:1) (vol/vol) selama 24 jam pada suhu $37^{\circ} \mathrm{C}$. Irisan ubi jalar ungu fermentasi selanjutnya diautoklaf $\left(121^{\circ} \mathrm{C}, 15\right.$ menit $)$ dan didinginkan $\left(4^{\circ} \mathrm{C}, 24\right.$ jam), perlakuan dilakukan untuk satu, dua dan tiga siklus. Irisan ubi jalar ungu kemudian dikeringkan $\left(80^{\circ} \mathrm{C}, 18 \mathrm{jam}\right)$, digiling dan diayak (80 mesh) untuk mendapatkan tepung ubi jalar ungu modifikasi. Kombinasi pemanasan bertekanan-pendinginan dengan fermentasi mampu meningkatkan kadar pati resisten pada tepung ubi jalar ungu modifikasi. Semakin banyak jumlah siklus pemanasan bertekanan-pendinginan yang diaplikasikan dapat meningkatkan kadar pati resisten secara signifikan. Perlakuan fermentasi dengan 1 siklus pemanasan bertekananpendinginan (FAC-1S) menghasilkan kadar pati resisten tertinggi $(11,26 \%)$ dibanding perlakuan lainnya dan meningkatkan kadar pati resisten sebesar 5,34 kali lipat dibandingkan perlakuan kontrol (2,11\%). Peningkatan kadar pati resisten menyebabkan terjadinya penurunan daya cerna pada tepung ubi jalar ungu modifikasi.

Kata kunci: bakteri asam laktat, fermentasi, pati resisten, pemanasan bertekanan-pendinginan, ubi jalar ungu

ABSTRACT: This study aimed to analyze the influence of mixed culture of lactic acid bacteria fermentation and autoclaving-cooling cycle for resistant starch content of modified purple sweet potato flour. Purple sweet potato slices had been fermented with mixed cultures of lactic acid bacteria (Lactobacillus plantarum B-307: Leuconostoc mesenteroides SU-LS 67) (1:1) (v/v) for 24 hours at $37^{\circ} \mathrm{C}$. Then, fermented purple sweet potato slices had been autoclaved $\left(121^{\circ} \mathrm{C}, 15 \mathrm{~min}\right)$ and cooled $\left(4^{\circ} \mathrm{C}, 24\right.$ hours), treatment was done for one, two and three cycles. Furthermore, purple sweet potato slices was done dried $\left(80^{\circ} \mathrm{C}, 18\right.$ hours), ground and sieved (80 mesh) to obtain modified purple sweet potato flour. Combination autoclaving-cooling and fermentation can increase levels of resistant starch of modified purple sweet potato flour. The more number of autoclaving-cooling cycle had been applied can increase significantly the levels of resistant starch. Treatment fermentation with autoclaving-cooling 1 cycles (FAC-1S) produced the highest resistant starch content $(11,26 \%)$ compared to other treatments and it increased levels of resistant starch by 5.34 -fold compared to control $(2,11 \%)$. Increased levels of resistant starch can contribute for decrease the digestibility of modified purple sweet potato flour.

Keywords: lactic acid bacteria, fermentation, resistant starch, autoclaving-cooling, purple sweet potato 


\section{Pendahuluan}

Salah satu bentuk inovasi dalam pemenuhan kebutuhan pangan adalah dengan usaha diversifikasi pangan. Diversifikasi pangan diharapkan dapat mengurangi ketergantungan masyarakat terhadap bahan makanan pokok tertentu. Ubi jalar merupakan komoditas sumber karbohidrat utama setelah padi, jagung, ubi kayu yang mempunyai peranan penting dalam penyediaan bahan pangan, bahan baku industri maupun pakan ternak. Menurut Hidayat et al., (2007) ubi jalar berpotensi untuk dikembangkan menjadi sumber karbohidrat alternatif. Ubi jalar ungu memiliki tekstur lebih berair, kurang masir, dan lebih lembut daripada ubi jalar putih, akan tetapi rasanya tidak semanis ubi jalar putih (Hasim \& Yusuf, 2008).

Karakteristik lain dari ubi jalar ungu yaitu kulit dan daging umbi yang berwarna ungu kehitaman. Apabila dibandingkan dengan ubi jalar ungu varietas lokal, ubi jalar varietas ayamurasaki memiliki intensitas warna ungu yang lebih pekat dan kadar antosianin yang lebih tinggi. Bahkan bila dibandingkan dengan ubi jalar varietas Yamagawa-murasaki, ayamurasaki memiliki kandungan antosianin empat kali lipat dari kandungan antosianin Yamagawamurasaki (Steed \& Truong, 2008). Komoditas ubi jalar ungu sangat layak dipertimbangkan dalam menunjang program diversifikasi pangan yang berbasis tepung karena memiliki kandungan nutrisi yang baik, umur tanam yang relatif pendek, produksi yang tinggi (Widodo, 1989). Selain itu, ubi jalar ungu juga merupakan salah satu komoditas yang berperan sebagai sumber serat pangan (dietary fiber) sehingga sangat bermanfaat sebagai sumber prebiotik.

Kandungan air ubi jalar ungu varietas Ayamurasaki masih cukup tinggi yaitu $67.77 \%$. Hal ini dapat mempersulit proses penyimpanannya. Menurut Setiawati et al., (1994), penyimpanan ubi jalar ungu pada suhu kamar selama satu bulan dapat menyebabkan kerusakan sebesar 15\%. Tekstur ubi jalar ungu yang lunak dengan kadar air tinggi memiliki sifat mudah rusak oleh pengaruh mekanis. Kerusakan ini memberi kesempatan masuknya mikroba ke dalam umbi dan merusak umbi secara keseluruhan. Pengolahan ubi jalar ungu menjadi tepung merupakan salah satu upaya pengawetan ubi jalar untuk memperpanjang umur simpannya. Selain itu, hal ini juga merupakan upaya peningkatan daya guna ubi jalar ungu supaya dapat dimanfaatkan sebagai bahan baku industri pangan. Pengolahan ubi jalar ungu menjadi tepung memberi beberapa keuntungan seperti meningkatkan daya simpan, praktis dalam pengangkutan dan penyimpanan, dan dapat diolah menjadi beraneka ragam produk makanan (Jiang, 2001). Di banyak negara, tepung ubi jalar digunakan sebagai suplementasi tepung terigu dalam pembuatan produk bakery, pancake, puding, dan lainnya. Manfaat yang terkandung dalam tepung ubi jalar ungu bergantung pada komposisi kimia umbi dan waktu pemanenan. Kandungan protein, amilosa dan serat tertinggi terdapat pada ubi jalar ungu yang dipanen pada bulan keempat dan akan menurun pada bulan kelima. Sementara itu kandungan gula pada ubi jalar ungu akan meningkat pada bulan kelima. Secara keseluruhan, waktu pemanenan yang optimum adalah bulan keempat karena tepung ubi jalar ungu yang dihasilkan akan memiliki kandungan nutrisi yang lebih baik (Jiang, 2001).

Kadar pati resisten dipengaruhi oleh kadar amilosa dan amilopektin. Kadar amilosa yang tinggi berbanding lurus dengan kadar pati resisten yang akan dihasilkan (Sajilata et al., 2006). Beberapa upaya peningkatan kadar pati resisten yang telah dilakukan, diantaranya melalui kombinasi fermentasi BAL dengan pemanasan otoklaf (Jenie et al., 2012) dan dengan kombinasi fermentasi spontan dengan pemanasan otoklaf (Abdillah, 2010) pada pisang tanduk, serta proses pemanasan bertekanan-pendinginan dengan 3 dan 5 siklus pada umbi garut (Sugiyono et al., 2009; Faridah et al., 2013). Kombinasi fermentasi kultur campuran BAL selama 72 jam dengan pemanasan bertekananpendinginan terbukti dapat meningkatkan kadar pati resisten (Jenie et al., 2012). Semakin banyak jumlah siklus autoclaving-cooling maka kadar pati resisten akan semakin meningkat (Faridah et al., 2013). Setiarto, (2015) melaporkan bahwa fermentasi kultur campuran bakteri asam laktat (Lactobacillus plantarum D-240 dan Leuconostoc mesenteroides SU-LS 67) penghasil amilase dan pululanase yang dilanjutkan dengan perlakuan 1 siklus pemanasan bertekanan-pendinginan mampu meningkatkan kadar pati resisten pada tepung talas 2,8 kali lipat jika dibandingkan dengan kontrol tanpa fermentasi.

Penelitian ini bertujuan menganalisis pengaruh fermentasi kultur campuran bakteri asam laktat dan siklus pemanasan bertekanan-pendinginan terhadap kadar pati resisten tepung ubi jalar ungu termodifikasi (Ipomea batatas Var Ayumurasaki). Hipotesis penelitian ini adalah perlakuan fermentasi kultur campuran bakteri asam laktat dan siklus pemanasan bertekanan-pendinginan dapat meningkatkan kadar pati resisten pada tepung ubi jalar ungu termodifikasi.

\section{Bahan dan Metode}

\subsection{Bahan}

Bahan baku yang digunakan adalah ubi jalar ungu (Ipomea batatas var Ayumurasaki) berumur 4 bulan yang diperoleh dari daerah Ciawi Bogor, Jawa Barat. Kultur bakteri Lactobacillus plantarum B-307 dan Leuconostoc mesenteroides SU-LS 67 koleksi Laboratorium Mikrobiologi Pangan, Bidang Mikrobiologi Pusat Penelitian Biologi LIPI. 


\subsection{Alat}

Peralatan yang digunakan dalam proses penelitian ini, diantaranya adalah autoklaf Hiarayama, spektrofotometer UV-VIS 1700 Shimazu (Japan), High Speed Refrigerated Sentrifuge Type 6500 Kubota (Japan), pin disc mill (mesin penggiling tepung), refrigerator, inkubator Isuzu (Japan), neraca analitik, hot plate, water bath, oven Kubota, pipet mikro Gilson, peralatan gelas seperti tabung reaksi, cawan petri, erlenmeyer dan gelas piala.

\subsection{Metode}

\subsubsection{Perlakuan fermentasi dan pemanasan bertekanan-pendinginan}

Pembuatan tepung ubi jalar ungu termodifikasi mengacu pada metode (Setiarto, 2015) dengan beberapa modifikasi. Ubi jalar ungu dikupas kulitnya, lalu diiris dengan ketebalan $\pm 1 \mathrm{~cm}$ kemudian direndam dalam larutan $\mathrm{NaCl} 1 \%$ (b/v) selama sehari semalam dan diganti setiap 3 jam untuk menghilangkan kandungan oksalat pada ubi jalar ungu. Setelah itu irisan ubi jalar ungu dicuci dengan air bersih mengalir dan ditiriskan. Perlakuan fermentasi dilakukan pada irisan ubi jalar ungu bebas oksalat dengan menggunakan kultur campuran bakteri asam laktat (Leuconostoc mesenteroides SU-LS 67 : Lactobacillus plantarum B307) rasio (1:1) (vol/vol), $10^{8} \mathrm{cfu} / \mathrm{mL}, 2 \%(\mathrm{v} / \mathrm{v})$ pada suhu $37^{\circ} \mathrm{C}$ selama 24 jam. Sementara itu untuk perlakuan pemanasan bertekanan-pendinginan, irisan ubi jalar ungu diautoclave pada suhu $121^{\circ} \mathrm{C}$ selama 15 menit, dengan rasio irisan ubi jalar ungu : akuades adalah 1 : $2(\mathrm{~b} / \mathrm{v})$, sehingga terjadi gelatiniasasi pada komponen pati ubi jalar ungu. Setelah itu dilanjutkan dengan pendinginan menggunakan refrigerator pada suhu $4^{\circ} \mathrm{C}$ selama 24 jam untuk memberikan dampak retrogradasi pada irisan ubi jalar ungu. Selanjutnya irisan ubi jalar ungu dikeringkan dengan oven pada suhu $80^{\circ} \mathrm{C}$ selama 18 jam, lalu ditepungkan dengan pin disk mill dan diayak sehingga diperoleh sampel tepung ubi jalar ungu berukuran 80 mesh.

Untuk mengetahui pengaruh perlakuan fermentasi bakteri asam laktat dan siklus pemanasan bertekanan-pendinginan (autoclavingcooling / AC) maka dilakukan pengelompokan tepung ubi jalar ungu. Desain riset yang digunakan dalam penelitian ini adalah Rancangan Acak Lengkap (RAL) yang dilanjutkan dengan uji Duncan pada taraf nyata $5 \%$. Proses pembuatan tepung ubi jalar ungu termodifikasi ditunjukkan oleh Gambar 1. Sementara itu perlakuan yang diberikan dalam penelitian ini disajikan pada Tabel 1.

Tabel 1

Perlakuan fermentasi dan siklus pemanasan bertekananpendinginan pada pembuatan tepung ubi jalar ungu termodifikasi

\begin{tabular}{|c|c|}
\hline Kode & Perlakuan yang diberikan \\
\hline $\mathrm{K}$ & $\begin{array}{l}\text { Kontrol, tanpa fermentasi tanpa siklus pemanasan } \\
\text { bertekanan-pendinginan }\end{array}$ \\
\hline AC-1S & $\begin{array}{l}\text { tanpa fermentasi, dengan } 1 \text { siklus pemanasan } \\
\text { bertekanan-pendinginan }\end{array}$ \\
\hline AC-2S & $\begin{array}{l}\text { tanpa fermentasi, dengan } 2 \text { siklus pemanasan } \\
\text { bertekanan-pendinginan }\end{array}$ \\
\hline AC-3S & $\begin{array}{l}\text { tanpa fermentasi, dengan } 3 \text { siklus pemanasan } \\
\text { bertekanan-pendinginan }\end{array}$ \\
\hline $\begin{array}{l}\text { Fermen } \\
\text { tasi }\end{array}$ & $\begin{array}{l}\text { fermentasi, tanpa siklus pemanasan bertekanan- } \\
\text { pendinginan }\end{array}$ \\
\hline FAC-1S & $\begin{array}{l}\text { fermentasi, dengan } 1 \text { siklus } \\
\text { bertekanan-pendinginan }\end{array}$ \\
\hline FAC-2S & $\begin{array}{l}\text { fermentasi, dengan } 2 \text { siklus } \\
\text { bertekanan-pendinginan }\end{array}$ \\
\hline
\end{tabular}

2.3.2. Analisis kimia terhadap tepung ubi jalar ungu termodifikasi

Ketujuh sampel tepung ubi jalar ungu termodifikasi tersebut selanjutnya dianalisis kadar total pati (Dubois et al., 1956), kadar gula pereduksi (Miller, 1959), kadar amilosa (Faridah et al., 2013), kadar pati cepat cerna (Rapid Digestible Starch/ RDS), pati lambat cerna (Slowly Digestible Starch/ SDS) dan kadar pati resisten (Engyst et al., 1992), daya cerna pati in-vitro (Anderson et al., 2002) sebanyak tiga kali ulangan.

\subsubsection{Analisis Statistika}

Data hasil penelitian untuk analisis kadar total pati, kadar amilosa, amilopektin, gula pereduksi, pati cepat cerna, pati lambat cerna, pati resisten dan daya cerna pati pada tepung ubi jalar ungu termodifikasi diolah secara statistik dengan analisis sidik ragam (ANOVA) menggunakan Software SPSS 17,0 . 


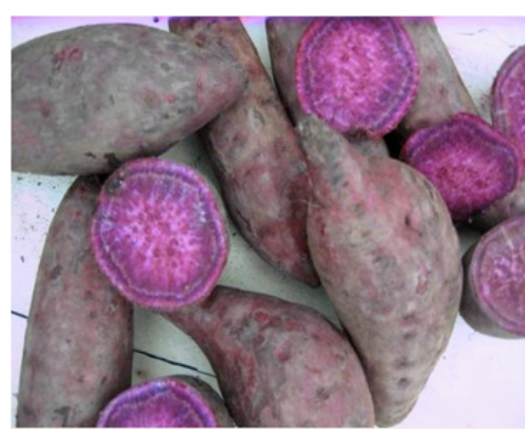

Ubi jalar ungu dipotong dan dikupas

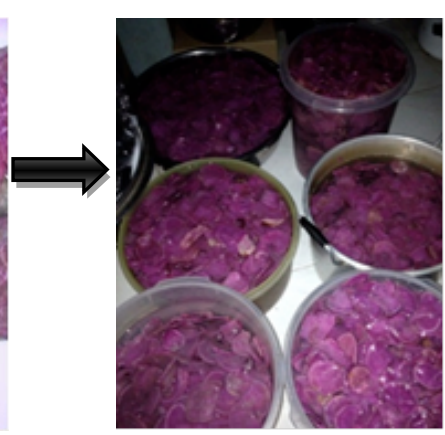

Irisan ubi jalar ungu direndam dalam larutan $\mathrm{NaCl} 1 \%$ (b/v)

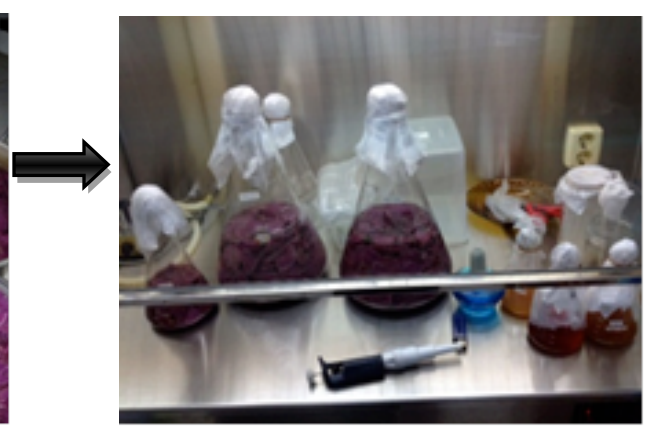

Irisan ubi jalar difermentasi dengan kultur campuran (Leuconostoc mesenteroides SU-LS 67 : Lactobacillus plantarum B-307) (1:1), $10^{8} \mathrm{cfu} / \mathrm{mL}$, $2 \%(\mathrm{v} / \mathrm{v})\left(37^{\circ} \mathrm{C}, 24 \mathrm{jam}\right)$

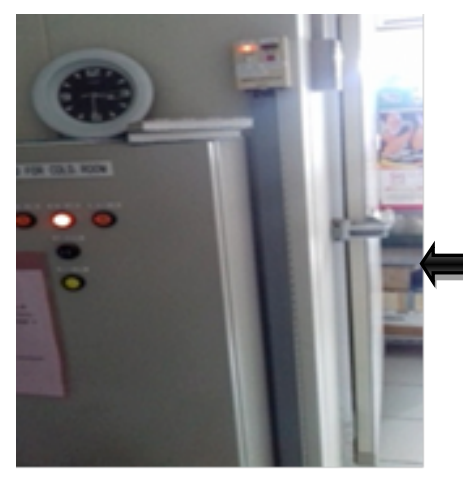

Irisan ubi jalar ungu didinginkan dalam refrigerator $\left(4^{\circ} \mathrm{C}, 24\right.$ jam $)$

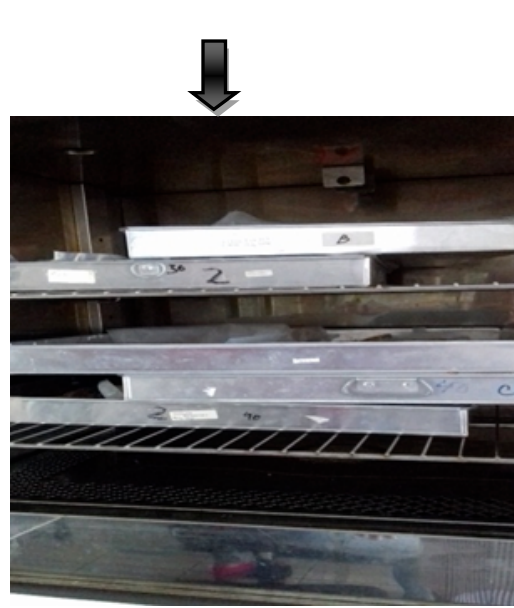

Pengeringan irisan ubi jalar ungu dalam oven $\left(80^{\circ} \mathrm{C}, 18 \mathrm{jam}\right)$

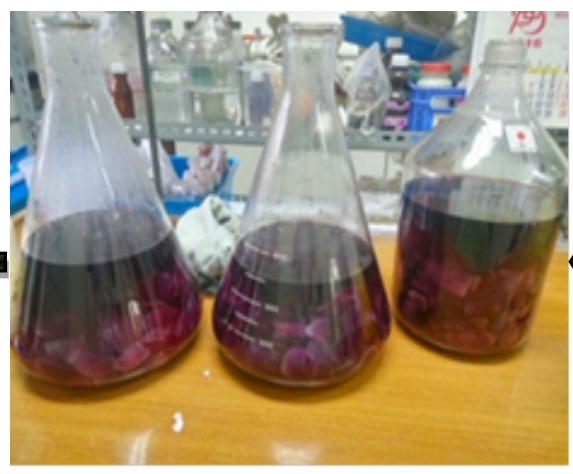

Irisan ubi jalar ungu diautoclaving $\left(121^{\circ} \mathrm{C}, 15\right.$ menit), rasio irisan ubi jalar ungu : akuades $(1: 2)$

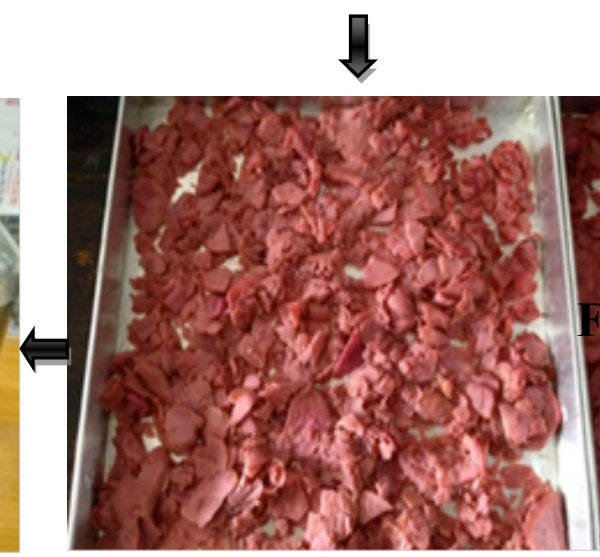

Irisan ubi jalar ungu setelah difermentasi

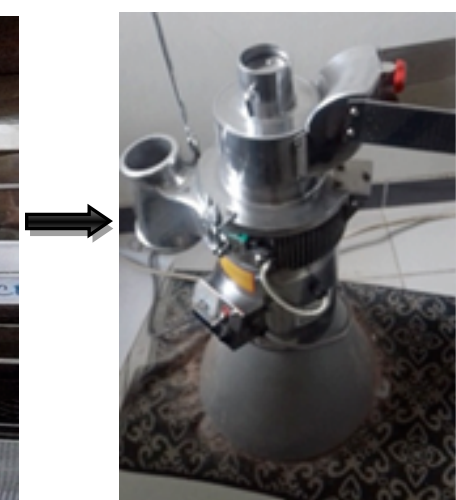

Penepungan ubi jalar ungu dengan pin disk mill

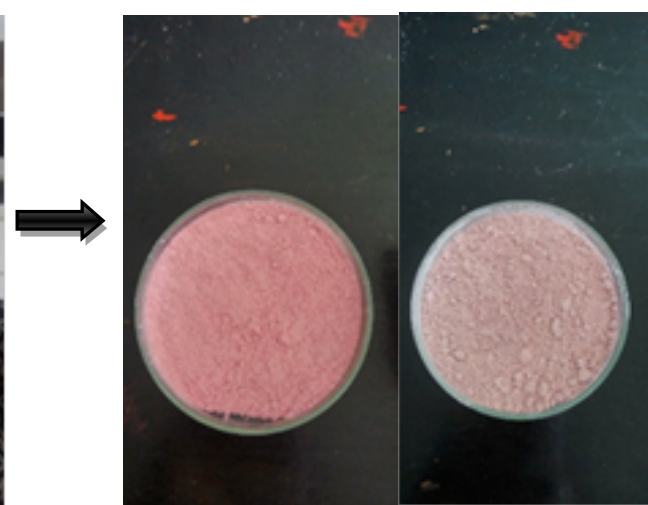

Tepung Ubi Jalar Ungu Termodifikasi (80 mesh)

Gambar 1. Proses pembuatan tepung ubi jalar ungu termodifikasi dengan fermentasi kultur campuran bakteri asam laktat dan siklus pemanasan bertekanan-pendinginan 


\section{Hasil dan Pembahasan}

\subsection{Kadar total pati tepung ubi jalar ungu termodifikasi}

Pati ubi jalar memiliki sifat (viskositas dan karakteristik lain) yang berbeda dari pati kentang dan pati jagung atau pati tapioka. Granula pati ubi jalar ungu berdiameter 2 - $25 \mu \mathrm{m}$. Granula pati ubi jalar ungu berbentuk poligonal dengan kandungan amilosa dan amilopektin berturut-turut adalah $20 \%$ dan $80 \%$ (Suda et al., 2003). Pati ubi jalar memiliki derajat pembengkakan 20 - $27 \mathrm{ml} /$ gram, kelarutan 15 - 35\% dan tergelatinisasi pada suhu $75-88^{\circ} \mathrm{C}$ untuk granula berukuran kecil (Suda et al., 2003). Hasil analisis kadar total pati (\% bk) terhadap tepung ubi jalar ungu modifikasi dapat dilihat pada Gambar 2 .

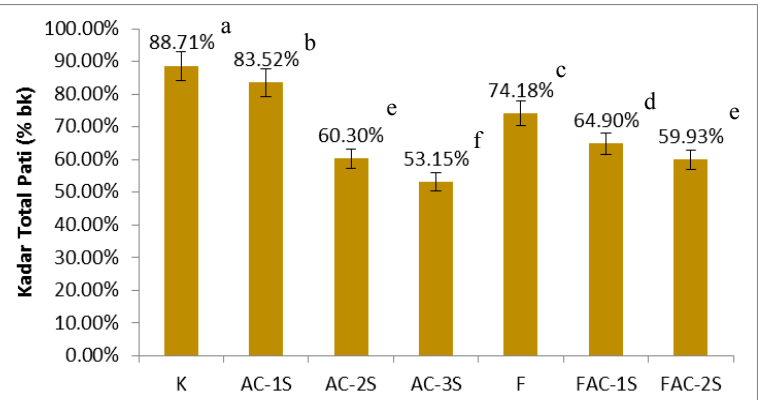

Gambar 2. Pengaruh fermentasi dan siklus pemanasan bertekanan-pendinginan terhadap kadar total pati tepung ubi jalar ungu modifikasi

Keterangan: Huruf yang berbeda pada diagram batang menunjukkan nilai yang berbeda nyata dengan taraf nyata 95 persen, $(\alpha=5 \%)$, setelah dilakukan uji Duncan pada SPSS 17.0

Kadar total pati tepung ubi jalar ungu modifikasi menunjukkan penurunan setelah diberi perlakuan fermentasi, pemanasan bertekanan-pendinginan beberapa siklus dan kombinasi fermentasi dengan pemanasan bertekanan-pendinginan. Semakin banyak jumlah siklus pemanasan bertekanan-pendinginan yang diaplikasikan berdampak terhadap penurunan kadar total pati tepung ubi jalar ungu modifikasi secara signifikan $(\mathrm{p}<0.05)$. Kadar total pati pada tepung ubi jalar ungu menurun akibat perlakuan fermentasi oleh kultur BAL L. plantarum B-307 dan Leu. mesenteroides SU-LS67 yang mampu menghidrolisis kandungan pati ubi jalar ungu. Kedua kultur BAL tersebut diketahui memiliki aktivitas enzim amilase dan pululanase yang tinggi (Setiarto et al., 2015). Menurut Bhanwar dan Ganguli, (2014) enzim amilase menghidrolisis ikatan linier $\alpha-1,4$ glikosidik pada amilosa secara acak menghasilkan campuran dekstrin, maltosa, dan glukosa. Sedangkan menurut Vatanasuchart et al., (2012) melaporkan bahwa enzim pululanase menghidrolisis ikatan percabangan $\alpha-1,6$ penghubung amilopektin sehingga dihasilkan amilosa rantai pendek. Selain itu Zaragoza et al., (2010) melaporkan bahwa penurunan kadar total pati juga dapat terjadi akibat putusnya ikatan glikosidik pada fraksi pati baik pada ikatan linier $\alpha-1,4$ amilosa dan ikatan percabangan $\alpha-1,6$ amilopektin oleh pemanasan autoklaf.

Perlakuan pemanasan bertekananpendinginan 3 siklus pada ubi jalar ungu dapat menurunkan kadar total pati ubi jalar ungu sangat signifikan jika dibandingkan dengan perlakuan yang lainnya. Pada penelitian lainnnya Jenie et al., (2012) dan Nurhayati et al., (2014) melaporkan bahwa proses fermentasi yang dilanjutkan dengan siklus pemanasan bertekanan-pendinginan menyebabkan penurunan kadar total pati secara signfifikan pada tepung pisang tanduk. Berdasarkan hasil analisa statistik ANOVA diketahui bahwa kadar total pati pada tepung ubi jalar ungu kontrol menunjukkan hasil yang berbeda nyata $(\mathrm{p}<0.05)$ dari tepung ubi jalar ungu AC-1S, AC-2S, AC-3S, fermentasi, FAC-1S, dan FAC$2 \mathrm{~S}$.

\subsection{Kadar amilosa dan amilopektin tepung ubi jalar ungu}

Perlakuan fermentasi, siklus pemanasan bertekanan-pendinginan dan kombinasi keduanya diketahui dapat menurunkan kandungan amilosa dan amilopektin pada tepung ubi jalar ungu modifikasi secara signifikan $(\mathrm{p}<0.05)$ (Gambar 3 dan Gambar 4).

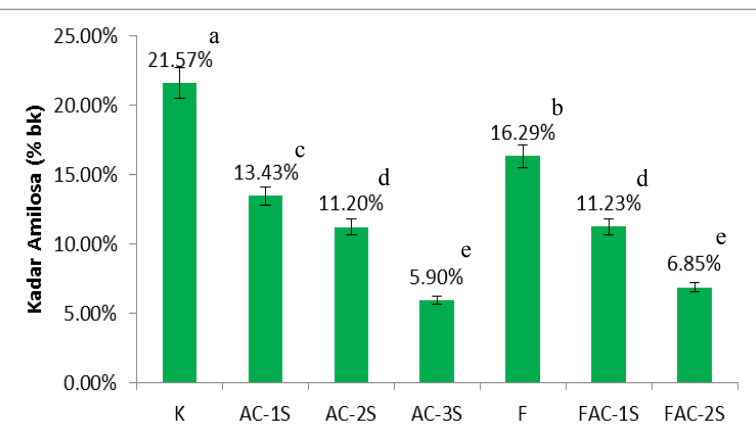

Gambar 3. Pengaruh fermentasi dan siklus pemanasan bertekanan-pendinginan terhadap kadar amilosa tepung ubi jalar ungu modifikasi

Keterangan: Huruf yang berbeda pada diagram batang menunjukkan nilai yang berbeda nyata dengan taraf nyata 95 $\%,(\alpha=5 \%)$, setelah dilakukan uji Duncan pada SPSS 17,0

Semakin banyak jumlah siklus pemanasan bertekanan-pendinginan yang diaplikasikan cenderung semakin menurunkan kadar amilosa dan amilopektin pada pati ubi jalar ungu. Hal ini disebabkan terjadinya kerusakan pada ikatan linier $\alpha$ 1,4- glikosidik pada amilosa maupun ikatan percabangan $\alpha$ 1,6- glikosidik pada amilopektin akibat pemanasan autoklaf. Perlakuan fermentasi dengan kultur campuran bakteri asam laktat dan kombinasi fermentasi 
dengan siklus pemanasan bertekananpendinginan diketahui juga mampu menurunkan kandungan amilosa dan amilopektin pada tepung ubi jalar ungu modifikasi secara signifikan $(\mathrm{p}<0.05)$.

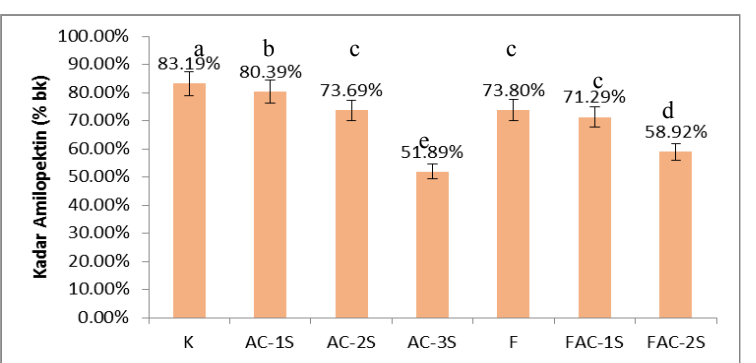

Gambar 4. Pengaruh fermentasi dan siklus pemanasan bertekanan-pendinginan terhadap kadar amilopektin tepung ubi jalar ungu modifikasi

Keterangan: Huruf yang berbeda pada diagram batang menunjukkan nilai yang berbeda nyata dengan taraf nyata 95 $\%,(\alpha=5 \%)$, setelah dilakukan uji Duncan pada SPSS 17.0

Penurunan kadar amilosa dan amilopektin menunjukkan bahwa kultur campuran bakteri asam laktat yang digunakan yaitu L. plantarum B307 dan Leu. mesenteroides SU-LS 67 mampu memproduksi enzim amilase dan pululanase dengan aktivitas yang tinggi selama fermentasi ubi jalar ungu (Setiarto et al., 2015). Enzim pululanase yang dihasilkan oleh kultur campuran BAL menghidrolisis amilopektin pada ikatan percabangan $\alpha-1,6$ selama fermentasi ubi jalar ungu (Bhanwar \& Ganguli, 2014). Sementara itu enzim amilase yang dihasilkan beroeran menghidrolisis ikatan linier $\alpha-1,4$ glikosidik pada amilosa. Rasio amilosa dan amilopektin pada ubi jalar ungu secara umum adalah $1: 3$ atau $1: 4$. Perbandingan kandungan antara amilosa dan amilopektin berperan penting dalam pembentukan adonan roti dan kue. Semakin besar kandungan amilopektin atau semakin kecil kandungan amilosa pati yang digunakan, maka semakin lekat produk olahannya (Kusnandar, 2011).

\subsection{Kadar gula pereduksi tepung ubi jalar ungu}

Gula pereduksi adalah monosakarida dan disakarida yang mempunyai gugus hidroksi bebas dan reaktif. Pada glukosa (aldose) biasanya terikat pada atom karbon nomor satu (anomerik), sedangkan pada fruktosa (ketosa) dengan gugus hidroksi reaktifnya terletak pada atom karbon nomor dua. Sementara itu laktosa mempunyai gugus hidroksi bebas pada atom $\mathrm{C}$ nomor satu pada rantai glukosanya (Kusnandar, 2011). Perlakuan fermentasi, pemanasan bertekananpendinginan beberapa siklus dan kombinasi fermentasi dengan pemanasan bertekananpendinginan secara umum memberikan pengaruh yang signifikan $(\mathrm{p}<0.05)$ dalam meningkatkan kadar gula pereduksi tepung ubi jalar ungu. Semakin banyak jumlah siklus pemanasan bertekanan-pendinginan yang diberikan maka semakin tinggi kadar gula pereduksi pada tepung ubi jalar ungu modifikasi. Pada penelitian ini tepung ubi jalar ungu yang diberi perlakuan 3 siklus pemanasan bertekanan-pendinginan menghasilkan peningkatan kadar gula pereduksi tertinggi dibandingkan perlakuan yang lain (Gambar 5).

Peningkatan kadar gula pereduksi selama pemanasan bertekanan-pendinginan terjadi akibat terbentuknya komponen monosakarida dan disakarida seperti maltosa dan glukosa. Hal tersebut terjadi karena putusnya ikatan glikosidik linier $\alpha-1,4$ pada komponen amilosa dan ikatan glokosidik percabangan $\alpha-1,6$ pada komponen amilopektin pati akibat pemanasan autoklaf. Perlakuan fermentasi diketahui juga meningkatkan kadar gula pereduksi secara signifkan karena kultur campuran bakteri asam laktat menghasilkan enzim amilase yang dapat menghidrolisis ikatan linier $\alpha-1,4$ glikosidik pada amilosa menjadi glukosa dan maltosa.

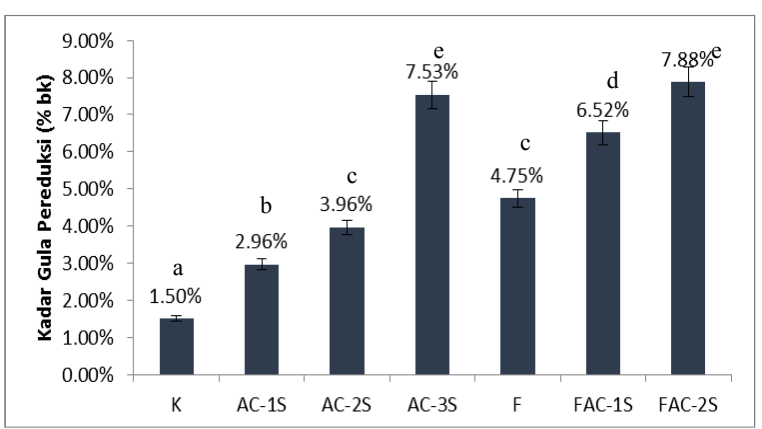

Gambar 5. Pengaruh fermentasi dan siklus pemanasan bertekanan-pendinginan terhadap kadar gula pereduksi tepung ubi jalar ungu modifikasi

Keterangan: Huruf yang berbeda pada diagram batang menunjukkan nilai yang berbeda nyata dengan taraf nyata 95 $\%,(\alpha=5 \%)$, setelah dilakukan uji Duncan pada SPSS 17.0

Berdasarkan hasil analisa statistik dengan ANOVA, diketahui bahwa perlakuan kontrol pada tepung ubi jalar ungu modifikasi menghasilkan kadar gula pereduksi yang berbeda nyata $(\mathrm{p}<0.05)$ jika dibandingkan perlakuan fermentasi, AC-1S, AC-2S, AC-3S, FAC-1S, FAC-2S.

3.4. Kadar pati cepat cerna (rapid digestible starch/ rds) dan pati lambat cerna (slowly digestible starch / sds) tepung ubi jalar ungu

Pati cepat cerna adalah fraksi pati yang menyebabkan kenaikan glukosa darah setelah makanan masuk ke dalam saluran pencernaan, sedangkan pati lambat cerna adalah fraksi pati yang dicerna sempurna dalam usus halus dengan kecepatan yang lebih lambat dibandingkan pati cepat cerna (Kusnandar, 2011). Pengaruh 
perlakuan fermentasi kultur campuran bakteri asam laktat dan siklus pemanasan bertekananpendinginan maupun kombinasi kedua perlakuan tersebut terhadap kadar pati cepat cerna (RDS) dan pati lambat cerna (SDS) tepung ubi jalar ungu modifikasi disajikan dalam Gambar 6. Berdasarkan hasil penelitian diketahui bahwa kadar RDS tepung ubi jalar ungu modifikasi mengalami penurunan secara signifikan $(p>0.05)$ akibat perlakuan fermentasi, maupun kombinasi fermentasi dengan siklus pemanasan bertekananpendinginan. Penurunan kadar RDS pada tepung ubii jalar ungu terjadi akibat selama proses fermentasi bakteri asam laktat cenderung lebih cepat untuk mengkonversi RDS menjadi gula sederhana seperti glukosa dan maltosa sebagai sumber karbon untuk pertumbuhannya. Karakteristik RDS yang relatif lebih mudah untuk dihidrolisis oleh enzim amilase dan pululanase selama fermentasi bakteri asam laktat membuat kandungannya mengalami penurunan secara signifikan $(\mathrm{p}<0.05)$.

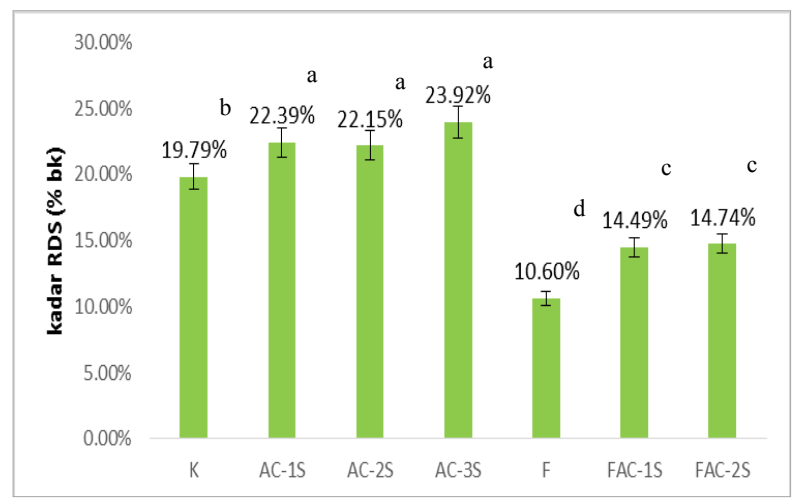

(a)

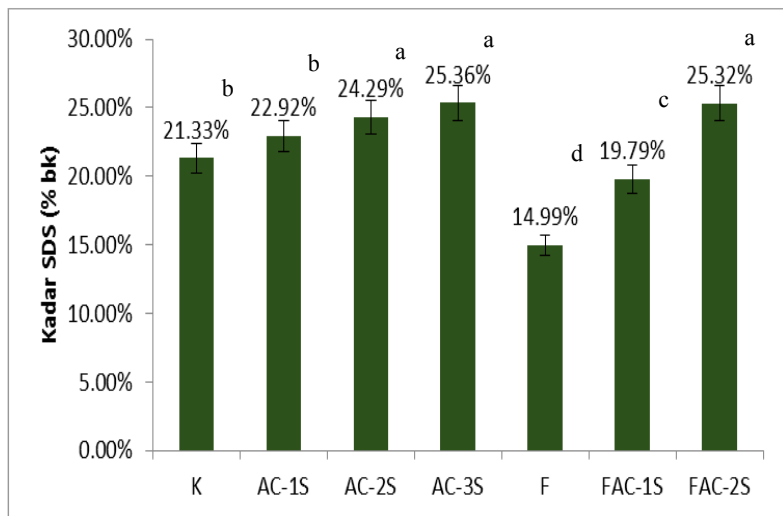

(b)

Gambar 6. Pengaruh fermentasi dan siklus pemanasan bertekanan-pendinginan terhadap kadar (a) RDS dan (b) SDS tepung ubi jalar ungu modifikasi

Keterangan: Huruf yang berbeda pada diagram batang menunjukkan nilai yang berbeda nyata dengan taraf nyata 95 persen, $(\alpha=5 \%)$, setelah dilakukan uji Duncan pada SPSS 17.0.

Sementara itu perlakuan pemanasan bertekanan-pendinginan meningkatkan kadar SDS (pati lambat cerna) pada tepung ubi jalar ungu modifikasi. Semakin banyak jumlah siklus pemanasan bertekananpendinginan yang diaplikasikan akan berpengaruh terhadap peningkatan kadar SDS tepung ubi jalar ungu modifikasi. Peningkatan kadar SDS terjadi akibat proses retrogradasi pati ubi jalar ungu akibat proses pemanasan bertekanan-pendinginan. Retrogradasi menyebabkan perubahan sifat-sifat gel pati diantaranya meningkatkan ketahanan pati terhadap hidrolisis enzim amilolitik dan kehilangan kemampuan untuk membentuk kompleks berwarna biru dan iodin (Ratnayake et al., 2002; Jane, 2004). Faktor-faktor yang mendukung terjadinya retrogradasi adalah suhu yang rendah, $\mathrm{pH}$ netral dan derajat polimerisasi yang relatif rendah, tidak adanya percabangan ikatan dari molekul, konsentrasi amilosa yang tinggi dan adanya ion-ion organik tertentu (Jane, 2004).

\subsection{Kadar pati resisten tepung ubi jalar ungu}

Hasil analisis kadar pati resisten terhadap tepung ubi jalar ungu termodifikasi dapat dilihat pada Gambar 7. Secara umum terjadi peningkatan kadar pati resisten secara signifikan $(p<0,05)$ pada tepung ubi jalar ungu termodifikasi akibat perlakuan pemanasan bertekanan-pendinginan (AC-1S, AC-2S, AC-3S) maupun kombinasi fermentasi dengan pemanasan bertekananpendinginan (FAC-1S, FAC-2S) jika dibandingkan dengan perlakuan kontrol dan fermentasi. Semakin banyak jumlah siklus pemanasan bertekanan-pendinginan yang diaplikasikan berpengaruh signifikan $(\mathrm{p}<0.05)$ terhadap peningkatan kadar pati resisten tepung ubi jalar ungu termodifikasi. Fenomena peningkatan kadar pati resisten tepung ubi jalar ungu modifikasi secara signifikan $(\mathrm{p}<0,05)$ setelah diberikan perlakuan pemanasan bertekanan-pendinginan beberapa siklus sesuai dengan penelitian Sugiyono et al., (2009) dan Faridah et al., (2013) pada pati garut maupun Jenie et al., (2012) dan Nurhayati et al., (2014) pada tepung pisang.

Perlakuan AC-1S (5,19 \%bk) meningkatkan kadar pati resisten sebanyak 2,46 kali lipat dibandingkan kontrol (2,11 \%bk). Sementara itu perlakuan AC-2S (8,78 \%bk) dan AC-3S (10,36 \%bk) semakin meningkatkan kadar RS berturutturut menjadi 4,16 kali lipat dan 4,9 kali lipat dibandingkan dengan kontrol (2,11 \%bk) (Gambar 7). Perlakuan kombinasi fermentasi dengan 1 siklus pemanasan bertekananpendinginan (FAC-1S) menghasilkan kadar pati resisten tertinggi (11,26 \%bk) pada tepung ubi jalar ungu modifikasi jika dibandingkan dengan perlakuan lainnya. Perlakuan tersebut terbukti mampu meningkatkan kadar pati resisten sebesar 
5,34 kali lipat jika dibandingkan dengan perlakuan kontrol $(2,11 \%$ bk). Sementara itu tepung ubi jalar ungu modifikasi dengan perlakuan FAC-2S (10,75 \%bk) meningkatkan kadar pati resisten secara signifikan menjadi 5,1 kali lipat jika dibandingkan dengan perlakuan kontrol (2,11 \%bk) (Gambar 7).

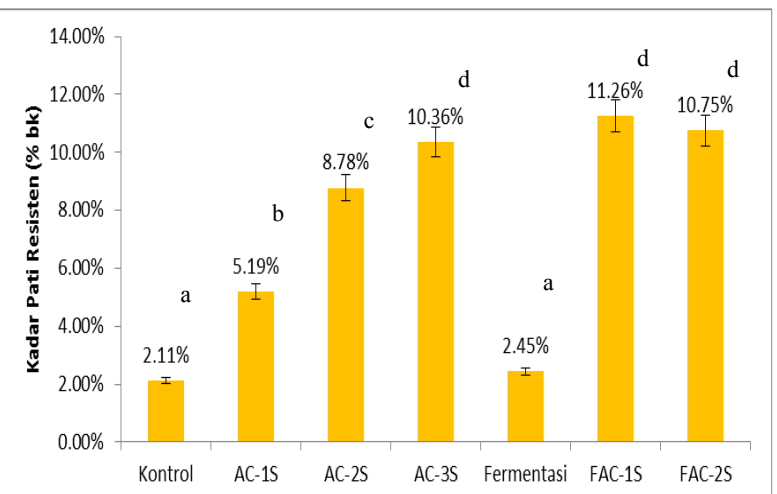

Gambar 7. Pengaruh fermentasi dan siklus pemanasan bertekanan-pendinginan terhadap kadar pati resisten tepung ubi jalar ungu modifikasi

Keterangan: Huruf yang berbeda pada diagram batang menunjukkan nilai yang berbeda nyata dengan taraf nyata 95 $\%,(\alpha=5 \%)$, setelah dilakukan uji Duncan pada SPSS 17.0

Peningkatan kadar pati resisten diakibatkan oleh terjadinya retrogradasi pada pati ubi jalar ungu. Pada saat tahap retrogradasi, molekul pati berupa amilosa maupun amilopektin akan saling berikatan kembali secara double helix sehingga membentuk struktur yang rapat dan stabil oleh ikatan hidrogen (Sajilata et al., 2006; Vatanasuchart et al., 2012). Granula pati yang kaya akan amilosa mempunyai kemampuan mengkristal yang lebih besar yang disebabkan oleh lebih intensifnya ikatan hidrogen. Pada saat pendinginan, rantai polimer terpisah sebagai ikatan ganda (double helix) dan mengalami pembentukan kembali ke struktur awalnya secara perlahan membentuk struktur kompak yang distabilkan oleh ikatan hidrogen (Karim et al., 2000). Adapun faktor-faktor yang mempengaruhi proses pembentukan pati resisten menurut Sajilata et al., (2006) diantaranya nisbah pati dan air atau konsentrasi pati, suhu autoclaving, jumlah siklus autoclaving-cooling, nisbah amilosa dan amilopektin, panjang rantai amilosa, hidrolisis asam (lintnerisasi) dan debranching amilopektin.

\subsection{Daya cerna pati in-vitro tepung ubi jalar ungu}

Daya cerna pati dapat diartikan sebagai kemampuan pati untuk dapat dicerna dan diserap dalam tubuh. Semakin tinggi daya cerna pati menunjukkan semakin tinggi pula pati untuk diubah menjadi glukosa, sehingga semakin tinggi pula kemampuan pati untuk menaikkan glukosa darah (Kusnandar, 2011). Analisis daya cerna pati merupakan salah satu parameter yang digunakan untuk mengetahui pengaruh perlakuan modifikasi pati, karena daya cerna pati dapat berkolerasi dengan kadar pati resisten yang dihasilkan (Anderson et al., 2002). Semakin rendah daya cerna pati terjadi akibat kandungan pati resisten dalam bahan pangan semakin tinggi. Perlakuan fermentasi $(F)$ berpengaruh signifikan $(p<0,05)$ meningkatkan daya cerna tepung ubi jalar ungu jika dibandingkan dengan kontrol (K) (Gambar 8). Sebaliknya perlakuan AC-1S, AC-2S, AC-3S, FAC$1 \mathrm{~S}$, dan FAC-2S berpengaruh signifikan $(\mathrm{p}<0,05)$ menurunkan daya cerna tepung ubi jalar ungu jika dibandingkan dengan kontrol (Gambar 8). Daya cerna pati ubi jalar ungu pada perlakuan AC-1S menunjukkan nilai yang tidak berbeda signifikan ( $p>0.05$ ) jika dibandingkan dengan perlakuan AC2S dan FAC-1S. Demikian halnya dengan daya cerna ubi jalar ungu pada perlakuan AC-3S yang juga menunjukkan nilai yang tidak berbeda signifikan $(p>0.05)$ dengan perlakuan FAC-2S.

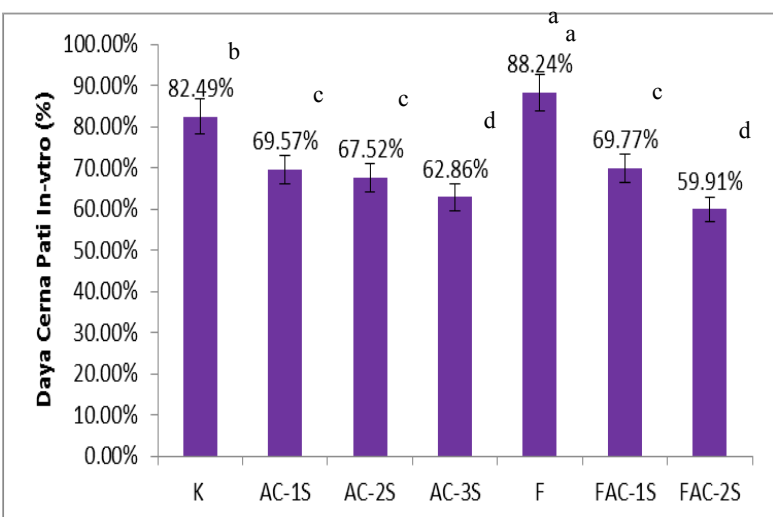

Gambar 8. Pengaruh fermentasi dan siklus pemanasan bertekanan-pendinginan terhadap daya cerna in-vitro tepung ubi jalar ungu modifikasi

Keterangan: Huruf yang berbeda pada diagram batang menunjukkan nilai yang berbeda nyata dengan taraf nyata 95 $\%,(\alpha=5 \%)$, setelah dilakukan uji Duncan pada SPSS 17.0

Peningkatan daya cerna pada perlakuan fermentasi (F) disebabkan oleh hidrolisis pati ubi jalar ungu oleh enzim amilase dan pululanase yang dihasilkan oleh kultur campuran bakteri asam laktat sehingga terbentuk amilosa rantai pendek, oligosakarida, maltosa, maltotriosa, glukosa yang lebih mudah dicerna dengan indeks glikemik yang tinggi. Penurunan daya cerna pada perlakuan pemanasan bertekanan-pendinginan berhubungan dengan meningkatnya kadar pati resisten dan serat pangan akibat proses retrogradasi sebagaimana penelitian Vatanasuchart et al., (2012) pada tepung pisang maupun Faridah et al., (2013) pada pati garut. Siklus autoclaving-cooling menyebabkan penurunan daya cerna pati melalui mekanisme penyusunan ulang molekul-molekul pati antara amilosa-amilosa, amilosa-amilopektin, amilopektin-amilopektin yang berdampak pada penguatan ikatan pada pati dan membuat pati 
lebih sulit untuk tercerna (Shin, 2004). Semakin banyak jumlah siklus pemanasan bertekananpendinginan yang diaplikasikan selama pembuatan tepung ubi jalar ungu modifikasi berdampak terhadap penurunan daya cerna tepung ubi jalar ungu secara signifikan $(\mathrm{p}<0.05)$.

\section{Kesimpulan}

Perlakuan pemanasan bertekanan pendinginan beberapa siklus dan kombinasi fermentasi dengan siklus pemanasan bertekanan pendinginan terbukti mampu meningkatkan kadar pati resisten pada tepung ubi jalar ungu modifikasi. Semakin banyak jumlah siklus pemanasan bertekananpendinginan yang diaplikasikan semakin meningkatkan kadar pati resisten tepung ubi jalar ungu modifikasi. Perlakuan fermentasi dengan 1 siklus pemanasan bertekanan-pendinginan (FAC1S) menghasilkan kadar pati resisten tertinggi $(11,26 \%)$ dibanding perlakuan kontrol $(2,11 \%)$, fermentasi $\quad(2,45 \%), \quad$ AC-1S $\quad(5,19 \%), \quad$ AC- $2 S$ $(8,78 \%)$, AC-3S $(10,36 \%)$ dan FAC-2S $(10,75 \%)$. Perlakuan fermentasi dengan 1 siklus pemanasan bertekanan-pendinginan (FAC-1S) (11,26\%) meningkatkan kadar pati resisten sebesar 5,34 kali lipat dibandingkan perlakuan kontrol (2,11\%). Peningkatan kadar pati resisten pada tepung ubi jalar ungu modifikasi berdampak pada penurunan daya cernanya. Penelitian lanjutan perlu dilakukan untuk mengevaluasi sifat prebiotik dan sifat amilografi dari pati resisten tepung ubi jalar ungu termodifikasi.

\section{Ucapan terima kasih}

Kegiatan penelitian ini didanai oleh DIPA Tematik Pusat Penelitian Biologi LIPI 2016-2017. Terima kasih yang sebesar-besarnya penulis sampaikan kepada Arumsyah Sumariyadi, Syarah Sukmawati, ibu Kasirah dan Nety Agustin yang telah membantu baik secara teknis maupun non teknis sehingga penelitian ini berjalan lancar.

\section{Daftar Pustaka}

Abdillah, F. (2010). Modifikasi Tepung Pisang Tanduk (Musa paradisiacal Formatypica) Melalui Proses Fermentasi Spontan dan Pemanasan Otoklaf Untuk Meningkatkan Kadar Pati Resisten. Tesis. Sekolah Pascasarjana, Institut Pertanian Bogor.

Anderson, A.K., Guraya, H.S., James, C. \& Salvaggio, L. (2002). Digestibility and pasting properties of rice starch heatmoisture treated at the melting temperature (Tm). I Starch/Stärke, 54, 401-409.

Bhanwar, S. \& Ganguli, A. (2014). $\alpha$-amylase and $\beta$ galactosidase production on potato starch waste by Lactococcus lactis subsp lactis isolated from pickled yam. Journal of Scientific \& Industrial Research, 73, 324-330.
Dubois, M., Gilles, K.A., Hamilton, J.K., Rebers, P.A. \& Smith, F. (1956). Calorimetric method for determination of sugars and related substances. J Analytical Chem, 28, 350-356.

Faridah, D.N., Rahayu, W.P. \& Apriyadi, M.S. (2013). Modifikasi Pati Garut (Marantha Arundinacea) dengan Perlakuan Hidrolisis Asam dan Siklus Pemanasan-Pendinginan Untuk Menghasilkan Pati Resisten Tipe 3. Jurnal Teknologi dan Industri Pangan, 23 (1), 61-69.

Hasim, A. \& Yusuf, M. (2008). Ubi jalar kaya antosianin pilihan pangan sehat. Jakarta: Sinar Tani.

Hidayat, B., Ahza, A.B. \& Sugiyono. (2007). Karakterisasi tepung ubi jalar (Ipomoea batatas L.) varietas shiroyutaka serta kajian potensi penggunaanya sebagai sumber pangan karbohidrat alternatif. Jurnal Teknologi dan Industri Pangan, 13(1), 32-39.

Jane. J.I. (2004). Starch: Structure and Properties. CRC Press LLC

Jenie, B.S.L., Reski, P.P. \& Kusnandar, F. (2012). Fermentasi Kultur Campuran Bakteri Asam Laktat dan Pemanasan Otoklaf Dalam Meningkatkan Kadar Pati Resisten dan Sifat Fungsional Tepung Pisang Tanduk (Musa parasidiaca formatypica). Jurnal Pascapanen, 9 (1), 18-26.

Jiang, X. (2001). Sweet potato processing and product research and development at the Sichuan Academy of Agricultural Sciences. Di dalam: Sweet Potato Post Harvest Research and Development in China. Proc. of an Int. Workshop at International Potato Center, pp 114-126.

Karim, A.A., Norziah, M.H. \& Seow, C.C. (2000). Methods for the study of starch retrogradation. Food Chemistry, 71, 9-36.

Kusnandar, F. (2011). Kimia pangan komponen makro. Cetakan Pertama. Jakarta: PT. Dian Rakyat.

Miller, G.L. (1959). Use of dinitrosalicylic acid reagent for determination of reducing sugar. J Analytical Chem, 31, 426428.

Nurhayati, Jenie, B.S.L., Widowati, S. \& Kusumaningrum, H.D. (2014). Komposisi Kimia dan Kristalinitas Tepung Pisang Termodifikasi Secara Fermentasi Spontan dan Siklus Pemanasan Bertekanan-Pendinginan. Agritech, 34 (2), 146-150.

Ratnayake, W.S., Hoover, R \& Warkentin, T. (2002). Pea starch: composition, structure and properties: a review. Starch/Starke, 54, 217-234.

Sajilata, M.G., Singhai, R.S. \& Kulkarni, P.R. (2006). Resistant starch a review. Comprehensive Reviews in Food Sci and Food Safety. Institute of Food Technologists.

Setiarto, R.H.B. (2015). Peningkatan Pati Resisten Tepung Talas Melalui Fermentasi dan Pemanasan BertekananPendinginan serta Evaluasi Sifat Prebiotiknya. Tesis. Sekolah Pascasarjana, IPB.

Setiarto, R.H.B., Jenie, B.S.L., Faridah, D.N., Saskiawan, I. \& Sulistiani. (2015). Seleksi Bakteri Asam Laktat Penghasil Amilase dan Pululanase dan Aplikasinya Pada Fermentasi Talas. Jurnal Teknologi dan Industri Pangan, 26 (1), 82-91.

Setiarto, R.H.B., Jenie, B.S.L., Faridah, D.N. \& Saskiawan, I (2015). Kajian Peningkatan Pati Resisten yang Terkandung dalam Bahan Pangan Sebagai Sumber Prebiotik. Jurnal Ilmu Pertanian Indonesia, 20(3), 191-200.

Setiawati, Y., Sudaryono \& Setyono, A. (1994). Studi Penyimpanan Ubi Jalar Segar. Dalam: Seminar Penerapan Teknologi Produksi dan Pascapanen Ubi Jalar untuk Mendukung Agroindustri Ubi Jalar.

Shin, S.I., Byun, J., Park, K.H. \& Moon, T.W. (2004). Effect of partial acid hydrolysis and heat-moisture treatment on formation of resistant tuber starch. Cereal Chem, 81, 194198.

Steed, L.E. \& Truong, V.D. (2008). Anthocyanin content, antioxidant activity,and selected physical properties of flowable purple-fleshed sweetpotato purees. Journal of Food Science, 73(5), 215-221.

Suda, I., Oki, T., Masuda, M., Kobayashi, M., Nishiba, Y. \& Furuta, S. (2003). Physiological functionality of purple-fleshed sweet potatoes containing anthocyanins and their utilization in foods. Japan Agricultural Research Quarterly (JARQ), 37 (3), 167 - 173. 
Sugiyono, Ratih, P. \& Faridah, D.N. (2009). Modifikasi pati garut (Marantha arundinacea) dengan perlakuan sikluas pemanasan suhu tinggi pendinginan (autoclaving - cooling cycling) untuk menghasilkan pati resisten tipe III. Jurnal Teknologi dan Industri Pangan, 20(1), 17-24.

Vatanasuchart, N., Niyomwit, B. \& Wongkrajang, K. (2012). Resistant starch content, in vitro starch digestibility and physico-chemical properties of flour and starch from Thai bananas. Maejo Int. J. Sci. Technol, 6(2), 259-271.
Widodo, Y. (1989). Prospek dan strategi pengembangan ubi jalar sebagai sumber devisa. Jurnal Penelitian dan Pengembangan Pertanian, 8 (4), 83-88.

Zaragoza, E.F., Riquelme-Navarrete, M.J., Sanchez-Zapata, E. \& Perez-Alvarez, J.A. (2010). Resistant starch as functional ingredient: A review. Food Research International, 43 (4), 931-94 